\title{
CITIZEN SCIENCE ENABLES A NEW LOCALITY RECORD FOR A CRITICALLY ENDANGERED TOAD, PELTOPHRYNE FLORENTINOI MORENO \& RIVALTA, 2007
}

\section{La ciencia ciudadana permite un nuevo registro de localidad para un sapo críticamente amenazado, Peltophryne florentinoi Moreno \& Rivalta, 2007}

\author{
Luis M. Díaz ${ }^{1}$, Jeffrey M. Lemm², Erick M. Briggs ${ }^{4}$, Sharon Clark ${ }^{4}$, Andrew L. Dannenberg ${ }^{4}$, \\ Russell G. Gamber ${ }^{4}$, Jane Kelly ${ }^{4}$, Patrick Laughlin ${ }^{4}$, Gary Markowski ${ }^{3}$, \\ Erin L. Shelley ${ }^{4}$, \& Adrian B. Van Bakel ${ }^{4}$
}

\footnotetext{
${ }^{1}$ Museo Nacional de Historia Natural de Cuba. luisfromcuba@yahoo.es.

${ }^{2}$ San Diego Zoo Institute for Conservation Research.

${ }^{3}$ Caribbean Conservation Trust.

${ }^{4}$ Caribbean Conservation Trust Herpetological Survey (October 6-15, 2018) participants.
}

\section{ABSTRACT}

The Zapata Toad (Peltophryne florentinoi) is reported from a new locality, Guajimico, which extends the distribution of this species to the Cienfuegos Province, in the central region of Cuba.

Keywords: West Indies, Cuba, Bufonidae, geographic distribution.

\section{RESUMEN}

Se registra al sapo Peltophryne florentinoi de una nueva localidad, Guajimico, lo cual extiende la distribución de la especie a la Provincia Cienfuegos, en la región central de Cuba.

Palabras clave: Antillas, Cuba, Bufonidae, distribución geográfica.

Citizen science has become a valuable tool for conservation, research, management and education programs for organisms throughout the world. Using data provided by amateur naturalists, citizen science has increased the scale of ecological research being done and the relationship between ecologists and the public (Dickinson et al., 2010). Data from citizen science programs are useful for studying changes in phenology, relative abundance, distribution, road mortality, survivorship, reproduction, and is particularly effective at finding rare organisms and disappearing native species, especially in urban areas (Dickinson et al., 2010; Spear et al., 2017). The following locality record was recorded during a herpetological ecotour of central Cuba, wherein the majority of tour participants lacked professional herpetological experience.

The Zapata Toad (Peltophryne florentinoi) is a locally endemic species that was assessed as Critically Endangered [B1 a, b (iii)] by the IUCN and Vulnerable (D2) by the Cuban Red Book (Rivalta, 2012: 89). The species was originally described by Moreno and Rivalta (2007) from the type locality: Girón, Zapata, Matanzas Province. Complementary information on adult morphology, a description of tadpoles and bioacoustical data were provided by Díaz and Cádiz (2008). Hernández et al. (2010) gave a more detailed description of the advertisement calls of this species. The phylogenetic relationships of this toad were discussed by Alonso et al. (2012). Alonso and Cobos (2016) reported P. florentinoi from a second locality: Guasasas, which is $20 \mathrm{~km}$ E of the type locality. 
On October 10 of 2018, a sub-adult male $P$. florentinoi was seen and photographed (Fig. 1), but not collected, by the authors at 20:54 hours in the Guajimico Village (Villa Guajimico: $21^{\circ} 55^{\prime} 41.63$ "; $80^{\circ} 18$ '42.13"), a tourist resort $42 \mathrm{~km}$ E of Cienfuegos City (Cienfuegos Province). The toad was posting directly on conical coastal limestone along a public trail. The new locality (Fig. 2) extends the distribution of P. florentinoi $52.54 \mathrm{~km} \mathrm{E} \mathrm{(32.65} \mathrm{mi)} \mathrm{from} \mathrm{Guasasas}$ (94.6 $\mathrm{km}$ by road).

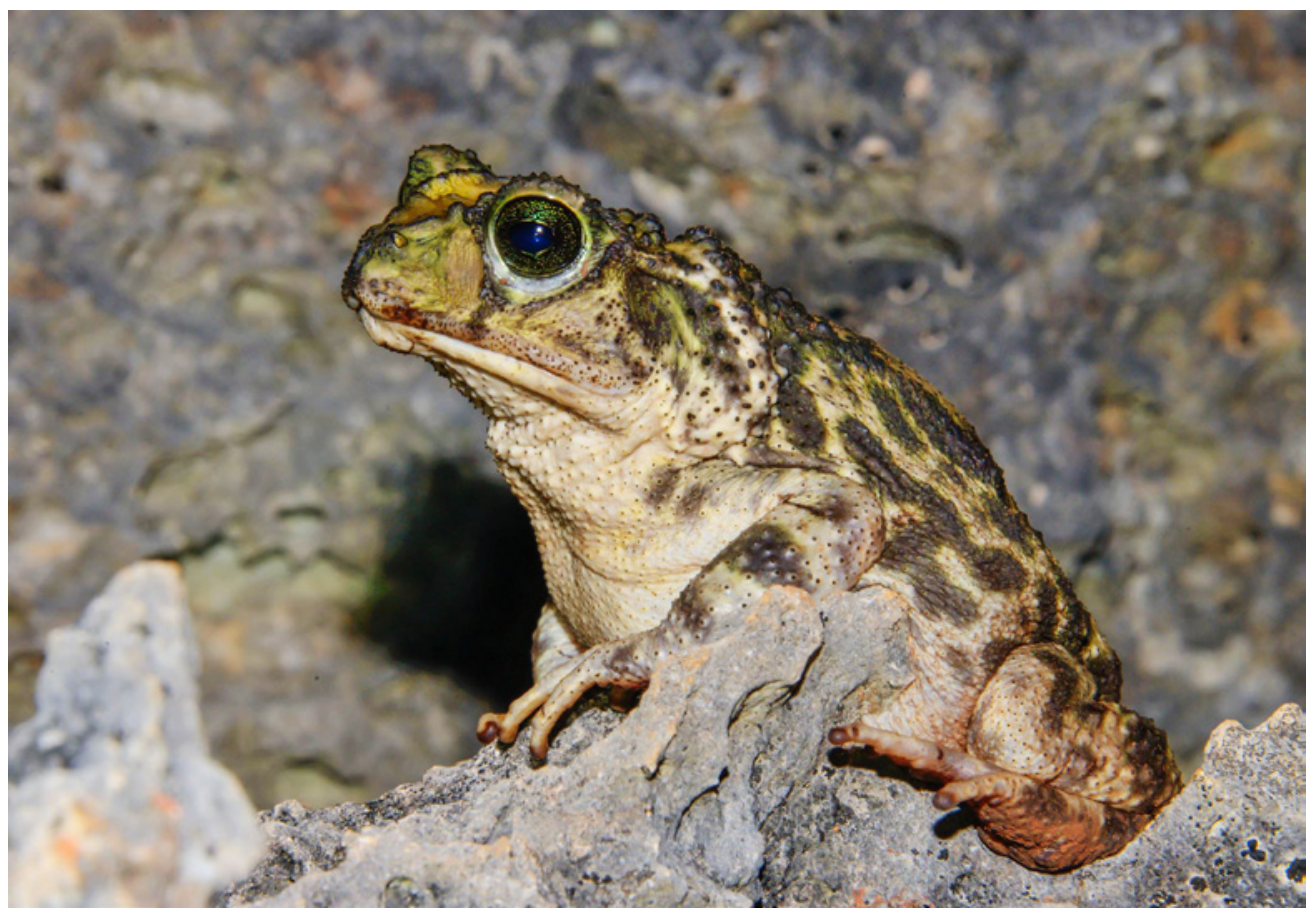

Figure 1. Peltophryne florentinoi, sub-adult male from Guajimico Village, Cienfuegos Province. Photo: Jeffrey M. Lemm.

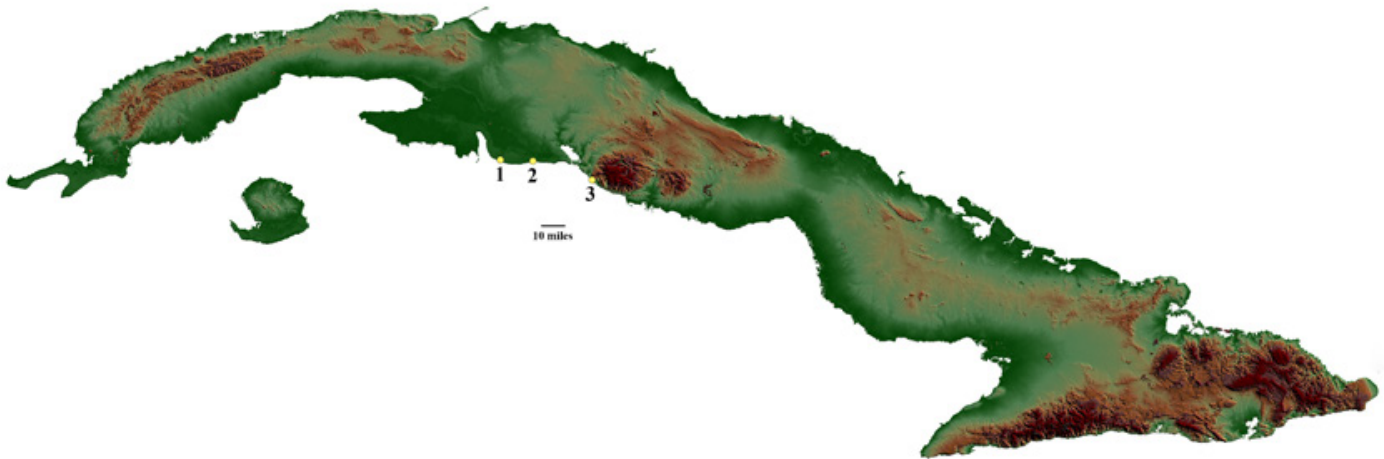

Figure 2. Distribution of P. florentinoi. (1) Type locality at Girón; (2) Guasasas, last distribution record by Alonso and Cobos (2016); (3) Guajimico Village, Cienfuegos. 
Further efforts to estimate the population size of the species in the new locality are necessary since only one individual was detected. The discovery is significant not only because of the conservation status of the species but it also confirms the biogeographic relationships of the eastern part of the Zapata region with central Cuba. The same kind of suitable habitat extends along the south coast to the vicinity of Trinidad (Sancti Spiritus Provinces), hence this toad may have a wider distribution in the region. At Guajimico, P. florentinoi coexists with P. peltocephalus (as it does in previously known localities); several individuals were observed around human habitations.

\section{LITERATURE CITED}

Alonso, R., and M. E. Cobos. 2016. A Rapid Survey of the Critically Endangered Zapata Toad, Peltophryne florentinoi (Anura: Bufonidae), in Cuba: New Locality and Conservation Approaches. IRCF Reptiles \& Amphibians, 23 (1): 10-15.

Alonso, R., A. Crawford, and E. Bermingham. 2012. Molecular phylogeny of an endemic radiation of Cuban toads (Bufonidae: Peltophryne) based on mitochondrial and nuclear genes. Journal of Biogeography, 39: 434-451.

Díaz, L. M., and A. Cádiz. 2008. Guía Taxonómica de los Anfibios de Cuba. Abc Taxa Vol. 4, 294 pp. + Audio CD.

Dickinson, J. L., B. Zuckerberg, and D. N. Bonter. 2010. Citizen Science as an Ecological Research Tool: Challenges and Benefits. Annual Review of Ecology, Evolution, and Systematics, 41: 149-172.

Hernández, M., R. Alonso, and A. Rodríguez. 2010. Advertisement call of Peltophryne florentinoi (Anura: Bufonidae), an endemic toad from Zapata Swamp, Cuba. Amphibia-Reptilia, 31: $265-272$.

Moreno, L. V., and V. Rivalta. 2007. Nueva especie de sapo del género Bufo (Anura: Bufonidae) de la Península de Zapata, Cuba. Solenodon, 6: 60-69.

Rivalta, V. 2012. Peltophryne florentinoi. Pp. 89-90. In: H. González, L. Rodríguez Schettino, A. Rodríguez, C. A. Mancina, and I. Ramos (Eds.), Libro Rojo de los Vertebrados de Cuba. Editorial Académica, La Habana, Cuba.

Spear, D. M., G. B. Pauly, and K. Kaiser. 2017. Citizen Science as a Tool for Augmenting Museum Collection Data from Urban Areas. Frontiers in Ecology and Evolution, 5: 86.

[Recibido: 20 de noviembre, 2018. Aceptado para publicación: 25 de diciembre, 2018] 